\title{
A Literature Review of Migrant Workers' Health and Safety
}

\author{
Yahya Thamrin \\ Department of Occupational Safety and Health, Faculty of Public Health, Hasanuddin University, \\ Indonesia
}

\begin{abstract}
Aims: To explore information regarding health and safety issues among migrant workers that represent substantial fraction of workforce in developed countries

Design/methodology/approach: A systematic search was conducted through PubMed, Scopus, Web of Science, Science Direct and Google Scholar using terms of interest in a logic grid from 1994 to 2018.

Findings: Many studies have found that numerous factors contribute to high number of work related accidents and injuries among this group. Lack of language, educational background and culture, exploitation, racism, discrimination and harassments and duration of residence are the main important factors that associated with accidents and injuries of this working population group.

Research limitations/implications: Number of publications might be not captured in this literature review. However, the findings range of studies have been analyzed and highlight the important to develop intervention among migrant workers to improve their health and safety conditions.

Originality/value: This paper supports the argument that migrant workers are in highly risk to experience accidents, injuries and fatalities in the workplace.
\end{abstract}

Keywords: Migrant Workers, Health and Safety, Accidents and Injuries 


\section{INTRODUCTION}

As a subpopulation of the workforce, the number of migrant workers is growing in some developed countries. The growth has produced a new mix of ethnicities in worker communities around the world. The potential impact of the growth to the work-related injuries and illness has been presented through some research. In the United States, McCauley (2005) reported that immigrant workers experience more accidents and injuries and worse severe outcomes than other groups of the whole working population.

There was a significant increase of the number of foreign-born workers' fatality rate in the US between 1998 and 2001 (Loh \& Richardson, 2004), as illustrated in Figure 1. In 1998, the fatality rate among migrant workers was below 4.5 fatalities per 100.000 and it increased to more than 5.5 fatal accidents per 100.000 employed in 2001. Otherwise, for native born workers and the overall population of workers, there was a decrease during the period of observation.

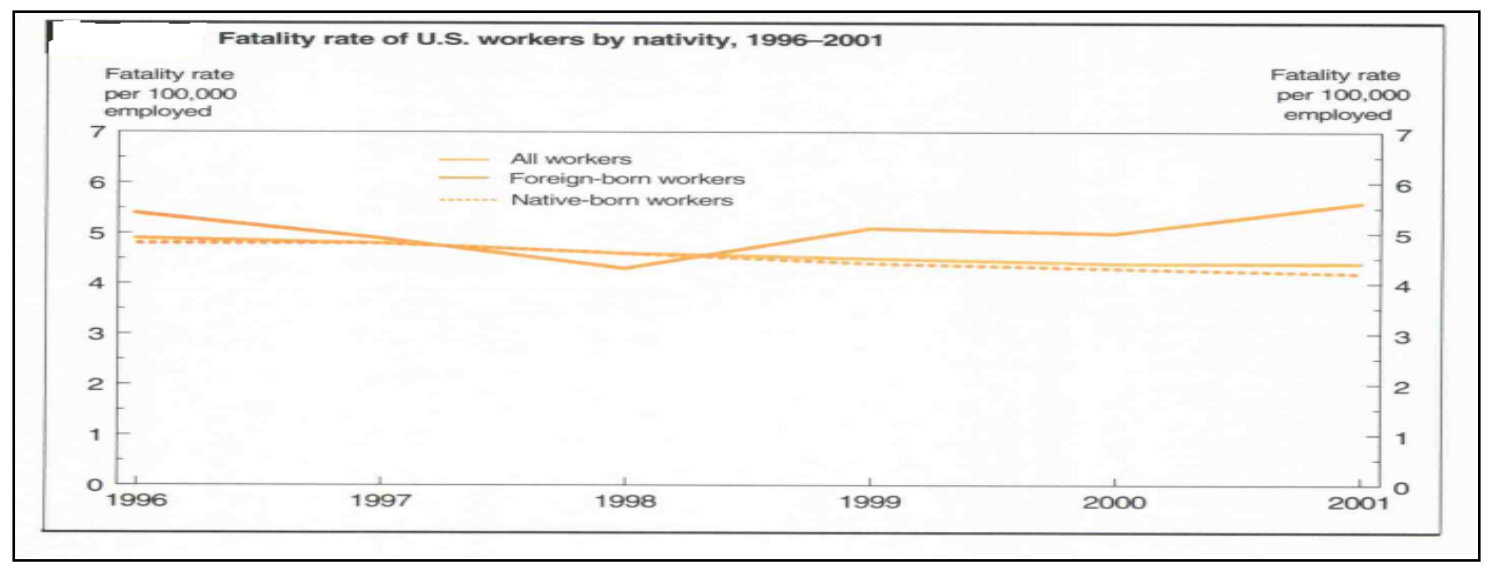

Figure 1. Fatality rate of US workers by nativity, 1996-2001 (Loh \& Richardson, 2004)

As a developed country with growing economy Australia is one of the main destinations of migrant workers from all over the world, particularly those from Asian countries (Thamrin, 2016). In November 2010, more than 1.4 million people came to Australia as immigrants. Around 1.2 million of them stayed as temporary residents and recent migrants. About 410,900 of them were categorised as permanent visa migrants, and approximately 308,700 of these immigrants obtained Australian citizenship. The largest component of this group was temporary migrants, including international students (approximately 477,800 people). Hawthorne (2005) claimed that in order to prevent the escalation of the number of migrant workers, the Australian Government has started a substantial review of policy related to migration in 1997 by gradually reducing the pathways for unskilled workers.

A similar pattern found in the US about work related fatalities has been reported in Australia. According to Corvalan et al. (1994), the standardised mortality ratio was significantly different between workers from a Non-English Speaking 
Background (NESB) and employees from an English Speaking Background

(ESB).

Table 1. Standardised mortality ratio* (SMR) for overseas-born persons and language group, by duration of residence

\begin{tabular}{|c|c|c|c|c|c|c|}
\hline \multirow{2}{*}{$\begin{array}{l}\text { Duration of } \\
\text { residence } \\
\text { (years) }\end{array}$} & \multicolumn{2}{|c|}{$\begin{array}{l}\text { Overseas-born } \\
\text { persons }\end{array}$} & \multicolumn{2}{|c|}{ English-speaking } & \multicolumn{2}{|c|}{$\begin{array}{l}\text { Non-English- } \\
\text { speaking }\end{array}$} \\
\hline & SMR & $95 \% \mathrm{CI}$ & SMR & $95 \% \mathrm{CI}$ & SMR & $95 \% \mathrm{CI}$ \\
\hline $0-1$ & 220 & $147-328$ & 124 & $64-239$ & 391 & $237-643$ \\
\hline $2-4$ & 167 & $114-243$ & 167 & $99-285$ & 165 & $97-281$ \\
\hline $5-9$ & 63 & 41-099 & 105 & $64-172$ & 25 & $9-065$ \\
\hline $10-14$ & 84 & $63-113$ & 74 & $48-114$ & 94 & $65-138$ \\
\hline $15-19$ & 97 & $71-131$ & 117 & $79-171$ & 76 & $47-124$ \\
\hline$\geq 20$ & 100 & $82-122$ & 97 & $69-135$ & 102 & $81-128$ \\
\hline
\end{tabular}

*Standardised by occupation to Australian-born population fatality rates $(95 \% \mathrm{CI}=$ 95\% Confidence Interval).

Source: Corvalan, 1994

The data provided in Table 1 shows that the mortality ratio was particularly elevated for people of NESB who had resided in Australia for less than five years. In other words, the highest incidence of work related fatalities was found among migrant workers who are relatively recent arrivals in Australia (Corvalan et al., 1994).

\section{METHODS}

A systematic search was conducted through PubMed, Scopus, Web of Science, Science Direct and Google Scholar using terms of interest in a logic grid with key words: Migrant worker OR Immigrant worker OR Migrant employee OR Migrant employment OR Migrant workers and health and safety. The articles in this search were limited to those published that relevant to the topic between 1994 and 2018.

\section{RESULTS}

Table 2 presents studies focusing on the health and safety of migrant workers. A systematic review about the immigrant population by Ahonen et al. (2007) revealed that developed countries had experienced an increased number of migrant workers, which had brought many social and economic problems for the host countries.

Table 2. A summary of the literature about migrant workers' health and safety

\begin{tabular}{|c|c|c|c|}
\hline $\begin{array}{l}\text { Category } \\
\text { of } \\
\text { literature }\end{array}$ & $\begin{array}{l}\text { Authors; } \\
\text { Country }\end{array}$ & Title & Main Findings \\
\hline $\begin{array}{l}\text { Systemati } \\
\text { c review }\end{array}$ & $\begin{array}{l}\text { Ahonen et } \\
\text { al. (2007); } \\
\text { Internation } \\
\text { al }\end{array}$ & $\begin{array}{l}\text { Immigrant } \\
\text { populations, } \\
\text { work and } \\
\text { health - a }\end{array}$ & $\begin{array}{l}\text { This paper reviewed the literature on } \\
\text { immigrant occupational health available } \\
\text { from recent studies. A systematic } \\
\text { investigation was performed in the PubMed }\end{array}$ \\
\hline
\end{tabular}


systematic journal database with a focus on terms such literature as immigration, migrant, occupational review health, occupational injury, and workers. Only articles in English and Spanish were reviewed in this study. This study demonstrated that migration has escalated in developed countries and has had political, social, and economic consequences for migrating groups, and also for their sending and host societies. Improving the health of immigrant workers requires more reliable data, targeted appropriate interventions, and enforcement of existing regulations.

Annual Moyce and Migrant Immigrant workers face high risk of review Schenker workers and occupational health and safety problems in (2018); their

United occupational the workplace that leads to high number of States health and injury and fatalities. The main causes are safety lack of OHS training and protections. Environmental exposure, working conditions, physical hazards, workplace demands, lack of safety standards and workplace abuse are contributing factors to the high number of accidents and injury among immigrant. Language and cultural barriers, access to health care, female gender, documentation status, and political climates are the predictive factors of injury.

$\begin{array}{lll}\begin{array}{l}\text { General } \\ \text { review }\end{array} & \begin{array}{l}\text { Hansen and } \\ \text { Donohoe }\end{array} & \begin{array}{l}\text { Health } \\ \text { issues of } \\ \end{array} \\ & (2003) ; & \text { migrant and } \\ & \text { United } & \text { seasonal } \\ & \text { States } & \text { farm } \\ & & \text { workers }\end{array}$

This study observed the socio-economic conditions of migrant and seasonal farmworkers (MSFWs) in the United States. The observation revealed that MSFWs form an under-served population with many socioeconomic and health problems. MSFWs' health problems are the result of occupational hazards, poverty, substandard living conditions, migrancy, and language and cultural barriers. These barriers also affect MSFWs' access to health care. 
Specific health challenges faced by MSFWs include infectious diseases, chemical and pesticide-related illnesses, dermatitis, heatrelated illnesses, respiratory conditions, musculoskeletal disorders, traumatic injuries, reproductive and child health problems, social and mental health problems, cancer, dental diseases and inadequate preventive care. This study suggested increasing attention, resources, education, and preventive services for MSFWs and families, as well as those who serve them.

General Loh and Foreign- This research identified trends in fatal work review Richardson born injury among foreign-born workers in the (2004); workers: United States from 1996-2001 using Bureau United Trends in of Labour Statistics surveillance data. The States fatal upward trend in workplace fatalities among occupational foreign-born workers over the 1996-2001 injuries, period reflects the large influx of foreign1996-2001 born workers, many of whom obtained employment in occupations and industries with inherently higher risk of fatal injury. Several factors are relevant to this observation, including lower level of education, low level of English proficiency, and the concentration of the foreign-born population in the metropolitan areas.

General Smith and Comparing The research examined the burden of workreview Mustard the risk of related injuries among immigrants to Canada (2009); work-related compared to Canadian-born labour force Canada injuries participants. The results of the study between revealed that male immigrants in their first 5 immigrants years in Canada are at increased risk of to Canada work-related severe injuries. This research and also proposed the need to study the barriers Canadian- faced by immigrants in obtaining safe born labour employment, the types of injuries that market immigrants experienced while working and 


\begin{tabular}{|c|c|c|c|}
\hline & & parti & e effect of injuries. \\
\hline $\begin{array}{l}\text { Empirical } \\
\text { study }\end{array}$ & $\begin{array}{l}\text { Corvalan et } \\
\text { al. (1994); } \\
\text { Australia }\end{array}$ & $\begin{array}{l}\text { Role of } \\
\text { migrant } \\
\text { factors in } \\
\text { work-related } \\
\text { fatalities in } \\
\text { Australia }\end{array}$ & $\begin{array}{l}\text { This research investigated the role of } \\
\text { workers' language and migration } \\
\text { characteristics regarding the incidents of } \\
\text { work-related fatalities in Australia. All work- } \\
\text { related fatalities occurring in Australia } \\
\text { during the period 1982-1984 were studied in } \\
\text { this research. This research found that } \\
\text { migrant workers had a similar fatality rate to } \\
\text { that of Australian-born workers in the } \\
\text { employed civilian labor force. However, } \\
\text { these groups had different injury incidents in } \\
\text { rural and mining occupations. Overseas-born } \\
\text { workers had a higher incident of injuries } \\
\text { compared to Australian-born workers. This } \\
\text { study also revealed that the mortality rate of } \\
\text { persons with non-English speaking } \\
\text { background with a duration of residence of } \\
\text { less than five years increased significantly } \\
\text { during this period. These values contributed } \\
\text { to the Australian rate with increasing } \\
\text { duration of residence. This study concluded } \\
\text { that factors related to origin country (such as } \\
\text { language) and migrant workers duration of } \\
\text { residence are significant determinants of } \\
\text { safety at work in Australia. }\end{array}$ \\
\hline $\begin{array}{l}\text { Empirical } \\
\text { study }\end{array}$ & $\begin{array}{l}\text { Bell et al. } \\
(2004) ; \\
\text { Ireland }\end{array}$ & $\begin{array}{l}\text { Migrant } \\
\text { workers in } \\
\text { Northern } \\
\text { Ireland }\end{array}$ & $\begin{array}{l}\text { The research argues that there is a continuing } \\
\text { debate about the difference between } \\
\text { immigrant and migrant workers. Long term } \\
\text { integration or settlement is associated with } \\
\text { the term of immigrant. On the other hand, } \\
\text { the term "migrant workers" implies the } \\
\text { possibility of returning to the home country } \\
\text { after migration or that the move is } \\
\text { temporary. Furthermore, it is reported that in } \\
\text { Northern Ireland migrant workers face a } \\
\text { range of problems related to low salary, } \\
\text { exploitation, harassment, racism, poor }\end{array}$ \\
\hline
\end{tabular}




\begin{tabular}{|c|c|c|c|}
\hline & & & housing, and safety problems. \\
\hline $\begin{array}{l}\text { Empirical } \\
\text { study }\end{array}$ & $\begin{array}{l}\text { Schubert } \\
\text { and } \\
\text { Dijkstra } \\
\text { (2009); } \\
\text { Netherland }\end{array}$ & $\begin{array}{l}\text { Working } \\
\text { safely with } \\
\text { foreign } \\
\text { contractors } \\
\text { and } \\
\text { personnel }\end{array}$ & $\begin{array}{l}\text { This research investigated the common } \\
\text { problems and best practices experienced by } \\
\text { multinational companies in the agricultural, } \\
\text { gas, and chemical industries in the } \\
\text { Netherlands when working with foreign } \\
\text { contractors and personnel. The study } \\
\text { identified five problematic areas: } \\
\text { communication/ language, uncertainty about } \\
\text { qualifications, safety culture, specific } \\
\text { employment situations, and cooperation } \\
\text { between principal and contractor. The } \\
\text { solutions and critical success factors named } \\
\text { by individual companies are examined and } \\
\text { best practice examples are given. }\end{array}$ \\
\hline $\begin{array}{l}\text { Empirical } \\
\text { study }\end{array}$ & $\begin{array}{l}\text { Guldenmun } \\
\text { d et al. } \\
\text { (2013); } \\
\text { Denmark, } \\
\text { Netherland } \\
\text { s and } \\
\text { United } \\
\text { Kingdom }\end{array}$ & $\begin{array}{l}\text { An } \\
\text { explanatory } \\
\text { study of } \\
\text { migrant } \\
\text { workers and } \\
\text { safety in } \\
\text { three } \\
\text { European } \\
\text { countries }\end{array}$ & $\begin{array}{l}\text { This study reported some reasons why } \\
\text { migrant workers are claimed as a vulnerable } \\
\text { group in the workforce; they generally have } \\
\text { insufficient language competency to } \\
\text { understand safety instructions in the country } \\
\text { in where they are engaged to work. } \\
\text { Furthermore, migrant workers are often } \\
\text { reliant on the experience from their origin } \\
\text { country. Moreover, the research reveals that } \\
\text { migrant workers are also likely to be } \\
\text { predominantly concerned about making as } \\
\text { much money as possible in their seasonal } \\
\text { jobs, such as in the agriculture and } \\
\text { construction industries. Hence, even though } \\
\text { they face a less than optimal working } \\
\text { environment, they will not complain. And } \\
\text { finally, the study revealed that there is a } \\
\text { substantial amount of migrant workers who } \\
\text { stay unregistered, which impacts on the } \\
\text { difficulties of determining the magnitude of } \\
\text { migrant workers' safety problems. }\end{array}$ \\
\hline
\end{tabular}




\begin{tabular}{|c|c|c|c|}
\hline $\begin{array}{l}\text { Comment } \\
\text { ary paper }\end{array}$ & $\begin{array}{l}\text { Underhill } \\
\text { (2010); } \\
\text { Australia }\end{array}$ & $\begin{array}{l}\text { Should host } \\
\text { employers } \\
\text { have greater } \\
\text { responsibilit } \\
\text { y for } \\
\text { temporary } \\
\text { agency } \\
\text { workers' } \\
\text { employment } \\
\text { rights? }\end{array}$ & $\begin{array}{l}\text { In order to protect temporary agency } \\
\text { workers' rights, the paper proposed sharing } \\
\text { responsibilities between both agency } \\
\text { employers and host employers. The author } \\
\text { believed that these shared responsibilities } \\
\text { may fill the gap between direct hire } \\
\text { employment conditions and their agency. } \\
\text { The study identified that on the one side the } \\
\text { employer agencies likely to provide less } \\
\text { support towards employment issues on the } \\
\text { work site that supposed to be shared with } \\
\text { host employers. On the other side, host } \\
\text { employers tend to decrease their } \\
\text { responsibility upon workers whom do not } \\
\text { directly work for them. }\end{array}$ \\
\hline
\end{tabular}

\section{DISCUSSIONS}

There are many publications suggest that migrant workers are in highly risk to experience accidents and injuries in the workplaces. Furthermore, some studies have identified factors that associated with the high number of incidents and injuries among this subgroup of working populations.

The studies in the United States, Canada, Netherlands, Denmark and United Kingdom claimed that language, educational background, and cultural barriers are the most determinant factors for health and safety problems of migrant workers (Guldenmund et al., 2013; Hansen \& Donohoe, 2003; Loh \& Richardson, 2004; Smith \& Mustard, 2009). Migrant workers experienced higher risk of fatal injuries because they do not always understand safety instructions well due to their low level of education and low level of the host country's language. Migrant workers prefer to utilize the safety knowledge and culture of their origin countries, but this is not always applicable in the host countries. Hawthorne (2005) claimed that in order to prevent the escalation of the number of migrant workers, the Australian Government has started a substantial review of policy related to migration in 1997 by gradually reducing the pathways for unskilled workers.

Lack of language skills also presents difficulties for migrant workers when attempting to communicate their needs or problems in the workplace to their employee. However, language and cultural problems can be solved by a proper approach to workers. Schubert and Dijkstra (2009) reported that three multinational companies in the agricultural, gas, and chemical industries in the Netherlands had successfully applied appropriate interventions to overcome the problems 
of culture and language when working with foreign contractors and personnel.

Besides language, educational background and culture, another factor that determined the safety in the workplace for migrant workers is duration of residence. Corvalan et al. (1994) stated that the mortality rate of migrant workers with a duration of residence of less than five years increased significantly during 19821984. This finding is supported by (Smith \& Mustard, 2009) who stated that immigrants in their first five years in Canada were at increased risk of work-related severe injuries.

In addition, migrant workers in European countries face a range of problems in the workplace such as low salary, exploitation, harassment, and racism, which in turn had a significant influence on the health and safety of migrant workers (Bell et al., 2004; Guldenmund et al., 2013). However, there was usually no complaint about their less than optimal working environment because they were focused on making money.

\section{CONCLUSIONS}

Migrant workers represent a significant number of working population in developed countries. A substantial number of studies have been conducted to explore the potential impact of the growing number of this sub-group regarding health and safety in the workplace. Many studies have found that numerous factors contribute to high number of work related accidents and injuries among this group. Lack of language, educational background and culture, access to health care, low safety standard, working conditions and duration of residence are the main important factors that associated with accidents and injuries of migrant workers. Moreover, this group also experiences exploitation, racism, discrimination and harassments that contribute as well to their health and safety status. To reduce the risks there are some ways to do such as safety training, improving working conditions and safety standards, better access to health care, and policy changes.

\section{REFERENCES}

Ahonen, E. Q., Benavides, F. G., \& Benach, J. (2007). Immigrant populations, work and health $-\mathrm{a}$ systematic literature review. Scandinavian journal of work, environment \& health, 96-104.

Bell, K., Jarman, N., \& Lefebvre, T. (2004). Migrant Workers in Northern Ireland: Institute for Conflict Research Belfast.

Corvalan, C. F., Driscoll, T. R., \& Harrison, J. E. (1994). Role of migrant factors in work-related fatalities in Australia. Scandinavian journal of work, environment \& health, 364-370.

Guldenmund, F., Cleal, B., \& Mearns, K. (2013). An exploratory study of migrant workers and safety in three European countries. Safety science, 52, 92-99.

Hansen, E., \& Donohoe, M. (2003). Health issues of migrant and seasonal farmworkers. Journal of Health care for the Poor and Underserved, 14(2), 153-164.

Hawthorne, L. (2005). "Picking winners": the recent transformation of Australia's skilled migration policy. 
International migration review, 39(3), 663-696.

Loh, K., \& Richardson, S. (2004). Foreign-born workers: trends in fatal occupational injuries, 1996-2001. Monthly Lab. Rev., $127,42$.

McCauley, L. A. (2005). Immigrant workers in the United States: Recent trends, vulnerable populations, and challenges for occupational health. American Association of Occupational Health Nurses Journal, 53(7), 313-319.

Moyce, S. C., \& Schenker, M. (2018). Migrant Workers and Their Occupational Health and Safety. Annual review of public health, 39, 351-365.

Schubert, U., \& Dijkstra, J. J. (2009). Working safely with foreign contractors and personnel. Safety science, 47(6), 786-793.

Smith, P. M., \& Mustard, C. A. (2009). Comparing the risk of workrelated injuries between immigrants to Canada and Canadian-born labour market participants. Occupational and Environmental Medicine, 66(6), 361-367.

Thamrin, Y. (2016). International students as young migrant workers in South Australia: The role of the University in occupational health and safety awareness and education.

Underhill, E. (2010). Should host employers have greater responsibility for temporary agency workers' employment rights? Asia Pacific Journal of Human Resources, 48(3), 338355. 